\title{
PANDANGAN TOKOH PESANTREN TERHADAP EKSISTENSI ULAMA PEREMPUAN DI KABUPATEN ACEH BARAT
}

\author{
IRMA JURAIDA \\ Dosen Jurusan Sosiologi Fakultas Ilmu Sosial dan Ilmu Politik \\ UNIVERSITAS TEUKU UMAR \\ Irmajuraida2@gmail.com
}

\begin{abstract}
This study discusses about Islamic figures boarding point of view toward "ulama" woman figure existence in West Aceh Regency. "The problem of the study of this thesis is analysis about how is point of view of social about existence.. This research is done in West Aceh Regency by using qualitative approach, especially by a much deeper interview technique method by meeting directly and observation. "Ulama" woman figure point of view is assumed as dialectic process (habitus, capital and field) and by time journey (history process and usuality) and influence by social environment (domain) that creating it. The result of this study shows that social point of view about existence "Ulama" woman figure is more fix by usuality, social background, culture and religious value that is comprehended by Islamic figures boarding or people or society group pertinent as a "Ulama" man figures friends and still contribution in woman capacity (taklim, local preachers, teachers or recitation teungku).
\end{abstract}

Key words: social view, Islamic figures boarding, existences "Ulama" woman figures 


\section{PENDAHULUAN}

Eksistensi ulama perempuan dalam masyarakat Islam masih menjadi pendebatan dikalangan masyarakat, tokoh agama maupun pemerintah. Masalah tersebut, terutama dalam pembagian kekuasaan di ranah publik antara laki-laki dan perempuan. Wacana pembagian kerja dan kekuasaan antara lakilaki dan perempuan yang berlaku selama ini dipandang bias laki-laki dan merupakan hasil praktik sosial melalui konstruksi dan internalisasi sosial budaya yang tidak berimbang termasuk dalam bidang ulama(Purnama:2006).

Ulama merupakan seorang yang berilmu agama secara mendalam dan menjadi panutan dalam masyarakat Islam sebagai pewaris Nabi. Dengan kata lain dapat dikatakan bahwa ulama merupakan salah satu kelompok orang yang mempunyai kedudukan dan posisi sentral dalam kehidupan masyarakat bersangkutan, sebagai penerus risalah agama Islam. Pergulatan (eksistensi) mereka tidak saja di bidang keagamaan, tetapi juga di bidang sosial-politik dan budaya (Ibrahim dalam Fairus: 2002).

Ulama dalam pandangan masyarakat Aceh, sampai saat ini masih mengacu pada kaum laki-laki, secara sosial-keagamaan menguasai kitab kuning dan memimpin pesantren. Kajian para ahli tentang ulama juga membuktikan demikian, nama tokoh laki-laki senantiasa menghiasi lembaran karya para peneliti tentang ulama. Pengetahuan masyarakat tentang ulama perempuan belum terbiasa, istilah ulama perempuan masih asing dalam masyarakat, bahkan bagi mereka yang terlibat dalam wacana sosial-intelektual. Oleh karena itu eksistensi ulama perempuan semakin bias (http:// www .rahima.or.id/:fokus-edisi-34).

Realitas sosial ini terlihat jelas dalam struktur masyarakat Aceh Barat, dimana keberadaan atau eksistensi ulama perempuan hanya berkiprah dalam ruang domestik (majelis taklim).

Hal ini mengakibatkan ulama perempuan sangat jarang dan sulit tampil di ranah publik (ceramah di hari besar Islam maupun dalam kegiatan lainnya diranah publik). Eksistensi dan kontribusi ulama perempuan bukan berarti tidak pernah ada, akan tetapi sangat sedikit berkiprah di ranah publik (wawancara dengan Ummi Hanisah ketua ulama perempuan Aceh Barat, tgl 10 Maret 2015).

Selain itu bila ditinjau dari segi kuantitas, keberadaan ulama perempuan belum menggembirakan bila dibandingkan dengan ulama laki-laki, hal ini dapat dilihat dalam tabel di bawah ini: 
Tabel 1.1

Komposisi Ulama diKabupaten Aceh Barat

\begin{tabular}{|c|c|c|l|}
\hline \multirow{2}{*}{ No } & \multicolumn{2}{|c|}{ Jumlah Ulama } & \multirow{2}{*}{ Kecamatan } \\
\cline { 2 - 3 } & Pr & Lk & \\
\hline 1 & 4 & 10 & Johan Pahlawan \\
\hline 2 & 4 & 12 & Kaway XVI \\
\hline 3 & 2 & 14 & Meureubo \\
\hline 4 & 1 & 11 & Arongan Lambalek \\
\hline 5 & 1 & 6 & Bubon \\
\hline 6 & - & 7 & Samatiga \\
\hline 7 & 1 & 5 & Woyla \\
\hline 8 & 2 & 13 & Woyla Timur \\
\hline 9 & 3 & 4 & Wayla Barat \\
\hline 10 & 2 & 4 & Panton Reu \\
\hline 11 & 2 & 5 & Pante Ceuremen \\
\hline 12 & - & 4 & Sungai Mas \\
\hline Jumlah & 22 & 92 & \\
\hline
\end{tabular}

Sumber: Dinas Syariat Islam (2014)

Berdasarkan tabel di atas komposisi ulama perempuan hanya 22,9\% dari jumlah ulama laki-laki di Kabupaten Aceh Barat. Atas dasar itu, diperlukan upaya-upaya sosial-politik lain dari masyarakat sipil (civil society), swasta (private), dan negara (state) yang memungkinkan terbangun alternatif sistem nilai-budaya (cultural-value system) yang lebih berimbang antara laki-laki dan perempuan, terutama dalam ranah kekuasaan publik. Sistem pemerintahan demokratis yang telah diterima sebagian besar masyarakat Aceh diharapkan dapat memberikan peluang bagi tumbuhnya konstruksi sosial-budaya yang lebih seimbang (gender equality) antara laki-laki dan perempuan dalam bermasyarakat dan bernegara.

Berdasarkan kondisi di atas eksistensi ulama perempuan (teungku inong atau ummi) dalam Kabupaten Aceh Barat belum begitu mengembirakan dan populer sehingga belum bisa berperan secara signifikan di tengah-tengah masyarakat. Masyarakat tidak hanya khawatir soal sistem nilai sosial budaya dan adat-istiadat yang berkembang tetapi, juga sistem nilai agama yang telah dihayati bersama. Bagaimanapun juga, sebutan ulama cenderung dilekatkan masyarakat Aceh pada kapasitas laki-laki, sehingga mereka mendapat peluang lebih besar untuk ambil bagian dan pro-aktif dalam persoalan yang menyangkut kebijakan (pemerintahan) negara dan masyarakat dalam menjaga budaya Aceh dari pengaruh internal dan eksternal (Amiruddin: 2003). 
Kepemimpinan Ulama perempuan dalam masyarakat Islam masih menjadi perdebatan dikalangan ulama di dunia, Indonesia bahkan di tingkat daerah. Aceh merupakan satu-satunya daerah legalisasi pelaksanaan syariat Islam di Indonesia termasuk Aceh Barat. Oleh karena itu mengetahui pandangan para Ulama di Aceh tentang eksistensi ulama perempuan yang masih menjadi polemik merupakan hal yang sangat penting, terutama pandangan tokoh-tokoh pesantren atau dayah di Aceh khususnya Aceh Barat. Berdasarkan permasalahan di atas, peneliti terdorong dan tertarik untuk meneliti tentang pandangan tokoh-tokoh pesantren terhadap eksistensi ulama perempuan di Kabupaten Aceh Barat, sehingga judul penelitian ini adalah "Pandangan Tokoh-Tokoh Pesantren terhadap Eksistensi Ulama Perempuan di Kabupaten Aceh Barat".

Berdasarkan uraian di atas, maka perumusan masalah dalam penelitian ini adalah: Bagaimanakah pandangan tokoh-tokoh pesantren atau dayah terhadap eksistensi ulama perempuan di Kabupaten Aceh Barat?

\section{TINJAUAN PUSTAKA}

Kerangka berfikir pandangan sosial dalam penelitian ini lebih didasarkan pada kebiasaan masyarakat (tokoh-tokoh pesantren) produk praktik sosial. Teori Praktik Sosial yang dikembangkan oleh Pierre Bourdieu (1990) menjelaskan tentang penekanan keterlibatan subjek (masyarakat pelaku sosial) dalam proses kontruksi dan internalisasi terhadap agen dalam suatu ranah. Teori praktik merupakan produk dari relasi antara habitus sebagai skema pemahaman, persepsi atau pandangan, dengan modal sebagai kekuatan agen dalam bermasyarakat dan ranah sebagai medan sosial.

Habitus sebagai sebuah konsep yang secara khas digunakan Bourdieu untuk menjelaskan praktik dalam kehidupan sosial. Habitus dianggap sebagai faktor yang membentuk dan mengembangkan pandangan agen dalam suatu ranah. Dengan kerangka pemikiran Bourdieu ini, pandangan seseorang dipahami sebagai hasil dari interaksi antara manusia sebagai subjek sekaligus objek dalam masyarakat, hasil dari pikiran sadar dan tak sadar, serta terbentuk sepanjang sejarah hidupnya. Teori praktik sosial dari Bourdieu menjelaskan bagaimana pandangan masyarakat terbentuk dan berperan dalam keseharian manusia dipadu oleh habitus yang dikontruksi dan diinternalisasikan oleh agen dalam ranah sebagai rangkaian skema orientasi hidup (Alfathri, 2009: 39).

Pandangan tokoh-tokoh persantren terhadap eksistensi ulama perempuan terjadi ketika ada interaksi sosial dalam suatu ranah. Atas dasar ini lah peneliti, menggunakan kerangka teoritik praktik sosial (habitus,modal dan ranah). Ulama-ulama perempuan dipahami sebagai gejala yang subjektif dan objektif. Pengetahuan atau pemahaman masyarakat (tokoh-tokoh pesantren) yang disebut pandangan sosial tentang eksistensi ulama perempuan dalam konteks 
ini dipahami sebagai suatu kenyataan yang ditentukan oleh tiga moment (ranah, modal dan habitus) tersebut sebagai praktik sosial.

Secara ringkas Bourdieu menyatakan rumus generatif yang menerangkan praktik sosial dengan persamaan $($ Habitus $\times$ Modal $)+$ Ranah $=$ Praktik Sosial . Praktik ini digunakan untuk menganalisis pandangan tokoh-tokoh pesantren terhadap eksistensi ulama perempuan.

\section{METODE PENELITIAN}

Penelitian ini adalah penelitian kualitatif karena dapat mengungkapkan secara mendalam tentang pandangan manusia dalam suatu realitas.

Tipe penelitian ini adalah studi kasus karena peneliti ingin mendapatkan pemahaman yang lebih baik tentang pandangan tokoh-tokoh dayah terhadap eksistensi ulama perempuan. Teknik pengumpulan data dalam penelitian ini adalah observasi, wawancara dan dokumentasi. Dengan teknik tersebut peneliti berada pada posisi untuk melihat seberapa jauh informan "mengatakan apa yang mereka maksudkan" dan "maksud apa yang mereka katakan".

Peneliti dalam hal ini berusaha untuk menangkap proses interpretasi produk praktik sosial, cara aktor menafsirkan peristiwa dalam bentuk pandangan sosial yang didasarkan pada kebiaasaan aktor dalam masyarakat.

\section{PEMBAHASAN}

Ulama berasal dari bahasa Arab a'lima yaitu orang yang berilmu dan ulama jamak dari a'lima yaitu orang-orang yang berilmu agama yang kuat atau luas dan mendalam, mengerti masalah atau hukum-hukum agama dan bisa dijadikan panutan dalam masyarakat. Kriteria seseorang disebut sebagai ulama dalam masyarakat Aceh Barat adalah orang berilmu dan kuat imannya baik muslim yang laki-laki maupun perempuan.

Ulama dipandang sebagai tempat umat Islam atau masyarakat muslim dalam menyelesaikan berbagai hal ikhwal tentang hukum Islam maupun sosial-budaya termasuk eksistensi ulama perempuan di ranah publik. Oleh sebab itu ulama di sebut sebagai pewaris Nabi, keberadaan ulama dalam masyarakat Islam sebagai penerang terhadap Al-Quran dan Al-Hadis. Walaupun demikian, fungsi dan peranan ulama dalam masyarakat menjadi salah satu fenomena sosial yang memunculkan berbagai istilah-istilah baru (ulama perempuan) yang dilekatkan kepada ulama (ulama laki-laki dan ulama perempuan). Gelar ulama bukan pemberian dari lembaga tertentu, melainkan pengakuan masyarakat yang melekat dengan sendirinya sesuai peran dan fungsinya dalam masyarakat (Purnama:2006).

Ulama dikalangan masyarakat Aceh Barat maupun dayah merupakan pimpinan (pengasuh) sebuah pesantren atau dayah yang memiliki pemahaman agama yang mendalam serta memiliki pengaruh dalam masyarakat. Ulama senantiasa diikuti dan diteladani dan memiliki pengaruh (power) baik 
dipesantren maupun dalam lingkungan masyarakat dibidang agama, sosial budaya maupun politik.

Para ulama ini tidak hanya eksis dalam pesantren, mengurus santri, akan tetapi mereka juga aktif memberikan pengajian di luar pesantren, seperti masjid-masjid di menasah atau mushala dan pada kegiatan-kegiatan perayaan hari besar Islam (seperti Maulid, Isra' mi'raj, Nuzul Quran dll). Secara umum ulama dayah dalam masyarakat Aceh terdiri dari ulama dayah tradisional dan terpadu.

Pandangan tokoh-tokoh dayah terhadap eksistensi ulama perempuan dalam konteks ini diasumsikan sebagai produk dialektika kontruksi ranah (pesantren atau dayah maupun masyarakat) modal sosial (kultural, sakral, interlektual maupun simbolik) dan internalisasi kebiasaan (habitus) terhadap seseorang yang keberadaannya dipandang masyarakat Aceh Barat sebagai ulama perempuan.

Dapat diasumsikan bahwa semakin positif konstruksi ranah dan internalisasi habitus seseorang terhadap ulama perempuan maka semakin positif pula pandangannya.

Berdasarkan temuan lapangan, latar belakang tokoh-tokoh dayah atau masyarakat representasif objektif pemerolehan informasi dan data penelitian ini banyak menentukan temuan mengenai pandangan sebagai pemahaman dari kebiasaan dalam masyarakat. Dengan kata lain, sistem nilai agama- budaya dan adat istiadat para informan (representasi masyarakat Aceh Barat) yang dijadikan landasan cara-pandang terhadap eksistensi dan kontribusi ulama perempuan lebih menentukan tingkat atau kondisi pandangan yang sedang berkembang dalam masyarakat.

Hasil penelitian pandangan tokoh-tokoh dayah mengenai eksistensi ulama perempuan berangkat dari landasan teori dari Pierre Bourdieu (praktik sosial). Asumsinya bahwa pandangan sosial tokoh-tokoh dayah merupakan fungsi dari momen-momen habitus, modal dan ranah terhadap eksistensi ulama perempuan yang diperhatikan dalam masyarakat. Dengan perkataan lain, tanggapan, informasi dan pandangan yang dikemukakan informan dalam konteks ini adalah hasil praktik sosial melalui kontruksi dan internalisasi momen habitus, modal sosial dan ranah atas fenomena tersebut, sehingga dapat diturunkan dalam beberapa pertanyaan.

Temuan empirik menunjukan bahwa tokoh-tokoh dayah representasi masyarakat Aceh Barat sudah memiliki pandangan positif terhadap keberadaan ulama perempuan dalam kapasitas perempuan. Dengan kata lain, temuan empirik penelitian ini belum memperlihatkan bahwa tokoh-tokoh dayah maupun masyarakat yang mendukung eksistensi dan kontribusi ulama perempuan dalam ranah publik sebagaimana ulama laki-laki. Pengalaman atas kebiasaan (habitus) dalam masyarakat seperti itu secara sosiologi mewujudkan realitas atas eksistensi dan kontribusi ulama perempuan dalam ranah publik berbeda dari ulama laki-laki yang sudah eksis dan diakui. 
Pandangan tokoh dayah tradisional dan modern berbeda terhadap eksistensi ulama perempuan dalam masyarakat. Menurut pandangan tokoh dayah tradisional menunjukkan bahwa ulama itu adalah mereka yang lahir di sekitar dayah, dibesarkan dalam lingkungan dayah, dan pada akhirnya mempunyai dayah dan santrinya sebagai tanggung jawab keagamaan dan kepemimpinannya adalah laki-laki. Kategori ulama yang dikemukakan di atas adalah salah satu gambaran yang dirujuk masyarakat Aceh Barat, utamanya kalangan komunitas ulama dayah tradisional.

Sedangkan pemahaman tokoh dayah terpadu tentang ulama perempuan yang dipahami dan diakui masyarakat masih sebagai mitra ulama laki-laki. Menurut sebagian besar informan di Kabupaten Aceh Barat, bahwa ulama perempuan tetap harus dibawah kepemimpinan ataupun pembinaan laki-laki, supaya sesuai dengan hukum agama maupun hukum adat dalam masyarakat.

Pandangan masyarakat tentang ulama perempuan, banyak ditentukan oleh jenis informasi yang diperoleh dalam pergaulan dan kebiasaan masyarakat. Kebiasaan dalam masyarakat bila dikaitkan dengan eksistensi ulama perempuan dan laki-laki terjadi kemajuan yang tidak paralel, eksistensi dan kontribusi ulama perempuan ketinggalan jauh dari laki-laki. Misalnya, laki-laki cenderung dapat memperoleh fasilitas lebih mudah dikenal masyarakat melalui aktifitas publik, melalui kegiatan membaca khutbah didepan jamaah Jum'at dan sebagainya (Purnama:2006). Perempuan tidak memiliki akses pada kegiatan publik yang lebih luas, mereka melakukan aktivitas atau hubungan dengan sesamanya melalui lembaga-lembaga pengajian majelis taklim, misalnya, itupun terbatas perlakuaan untuk kaum perempuan saja (Wawancara dengan Teungku M. Nahgru, MH pengasuh dayah Nahrul Ulum Diniyahislamiyah, representasi ulama tradisional, tanggal 7 Maret 2015).

Pengakuan masyarakat pada keberadaan seseorang atau kelompok sebagai ulama perempuan sering sekali tergantung pada kondisi sosial budaya tempatan. Pengetahuan warga masyarakat tentang ulama perempuan, oleh karena itu, banyak ditentukan oleh jenis informasi dan macam pendidikan yang diperoleh mereka dalam pergaulan dan kebiasaan mereka. Umumnya masyarakat Aceh memandang perempuan dari sudut perbedaan biologis. Pandangan itu yang cenderung mendasarkan cara-pandang laki-laki terhadap perempuan. Banyak informan yang ditemui menyebutkan hampir tidak mungkin perwujudan kesetaraan gender dilakukan karena berbagai hal yang berkaitan dengan perempuan menduduki posisi lemah itu (Purnama, 2006:81).

Ulama perempuan yang jarang ditemukan diranah publik dalam masyarakat Aceh itu karena tidak memenuhi kriteria ulama sebagaimana berkembang di kalangan laki-laki, yakni mampu menjadi pemimpin publik yang diakui dalam masyarakat bersangkutan. Berbagai dogkrin atau dogma yang dihayati dan diamalkan masyarakat sejak masa silam di jadikan tameng 
untuk melestarikan pembagian kerja laki-laki dan perempuan yang bias gender dan didukung pandangan sosio-biologis.

Secara umum pandangan tokoh-tokoh dayah maupun masyarakat tentang eksistensi dan kontribusi ulama perempuan sangat positif dalam kapasitas tertentu. Eksistensi dan kontribusi ulama perempuan dalam masyarakat Aceh Barat dipandang lebih cenderung sebagai mitra ulama laki-laki. Eksitensinya lebih pantas perempuan dengan perempuan pada tempat dan ruang tertentu karena suara adalah aurat. Ulama perempuan berdakwah harus sesuai kodrat perempuan sebagai istri dan ibu bagi anak. Selain itu hal yang paling utama karena ajaran agama yang dihayati bersama dalam masyarakat menganjurkan perempuan untuk berbakti kepada suami. Hal ini antara lain disebabkan figur ulama perempuan bersangkutan lebih didasarkan pada fakta adat-istiadat dan ajaran agama yang dihayati bersama dalam realitas sosial.

\section{PENUTUP}

Ulama dipandang dalam masyarakat di Kabupaten Aceh Barat lebih cenderung sebagai panggilan kewajiban publik yang lebih cocok bagi aktifitas kaum laki-laki dan sesuai dengan agama dan kebiasaan dalam masyarakat maupun kepantasan adat. Konsep kesejajaran antara ulama laki-laki dan perempuan dianggap sebagai konsep jender dan merupakan pemikiran masyarakat Barat yang tidak dihayati atau dianut oleh masyarakat Aceh Barat. Jadi ulama perempuan dipandang oleh tokoh-tokoh dayah tradisional maupun masyarakat sebagai mitra ulama laki-laki yang eksistensinya harus sesuai kodrat perempuan.

\section{DAFTAR PUSTAKA}

Adlin, Alfathri. 2009. Resistensi Gaya Hidup: Teori dan Realitas. Jakarta: Jalasutra.

Abduh, Dahlan. 1998. Peran Ulama dalam Memasyarakatkan Keluarga Kecil Bahagia Sejahtera di Kabupaten Pidie. Banda Aceh: IAIN Ar-Raniry.

Abduh Wahid. Perempuan Aceh antara Budaya dan Syariat. Jurnal Subtantia. Vol. 12. No. 02. Oktober 2010.

Badan Pusat Statistik. 2014. Aceh Barat Dalam Angka, Banda Aceh: Badan Pusat Statistik

Berger, L, Peter dan Thomas Luckmann. 1990. Tafsir Sosial atas Kenyataan (terjemahan Hasan Basri) Jakarta: LP3ES.

Black, James A and Dean J.C. 1992. Method and Issues in Social Reseach (Metode dan Masalah Sosial (terjemahkan E Koeswara dkk). Bandung: Eresco. 
Community; Volume 2, Nomor 3, Oktober 2016

ISSN: 2477-5746

Bourdieu, Piere. 1990. The Logic of Practice. USA: Standaford University Press

Burhanuddin, Jajat. 2002. Ulama Perempuan Indonesia. Jakarta: Gramedia Pustaka Utama.

Bungin, Burhan. 2001. Metodologi Penelitian Sosial Format-Format Kuantitatif dan Kualitatif. Jakarta: PT. Rajagrafido Perseda.

Craib, Ian. 1986. Teori-Teori Modern: dari Parson sampai Habermas. Jakarta: Rineke Cipta.

Darma, Yoce Aliah. 2013. .Analisis Wacana Kritik. Bandung: Margahayu Permai

Djamari, 1993. Agama dalam Perspektif Sosiolog. Bandung: CV Alfabeta.

Durkheim. 1984. Sociologi of Religion. London: Routledge and K. Paul

Fairus, M, Nur (ed) 2002. Syariat di Wilayah Syariat: Pernik-Pernik Islam di Nanggro Aceh Darussalam. Banda Aceh: Dinas Syari'at.

Fathoni, Abdurrahmat. 2006. Metodologi Penelitian dan Teknik Penyususan Skripsi,dan Tesis Jakarta: Rineka Cipta.

Gani, Isa Abdul. 2013, Fomalitas Syariat Islam di Aceh (Pendekatan Adat, Budaya dan Hukum. Banda Aceh: Yayasan PeNa.

Gazalba, Sidi. 1971. Pondok Pesantren dalam Kurun Pembangunan. (Jakarta: Departemen Agama RI.

Hasbi, Amiruddin. 2003. Ulama Dayah: Pengawal Agama M asyarakat Aceh(Terjemahan. Kamarudzaman. Bustamam-Ahmad). Lhokseumawe: Nadiya Foundation.

Husni, Jalil. 2007 . Fungsi Majelis Permusyawaratan Ulama Dalam Pelaksanaan Otonomi Khusus Di Provinsi Nanggroe Aceh Darussalam. Jurnal Ilmiah: Equality. Vol. 12. No. 2. Agustus 2007.

Idrus, Muhammad. 2007, Metode Penelitian Ilmu Sosial: Pendekatan Kualitatif dan Kuantitatif. Yogyakarta: Erlangga. 
Imran, Muhammad. 2000. Peran Aburrauf (ulama) Singkir pada masa Pemerintah Ratu di Aceh. Tesis. Pasca Sarjana IAIN (UIN) Syarif Hidayatullah. Jakarta.

Indah, Ahdiah. Peran-Peran Perempuan dalam Masyarakat. Jurnal Akademika Fisip Untad. Vol. 05. No. 02. Oktober 2013.

Jenkins, Richard. 2004. Membaca Pikiran Pierre Bourdieu. Jakarta: Kreasi Wacana.

Kasjim, Salenda. Kepemimpinan Perempuan dalam Perspektif Islam. Jurnal Ilmiah: Ar-Risalah Makasar. Vol. 12. No.2 Nopember 2012.

Kurdi, Muliadi. 2014. Menelusuri Karakteristik Masyarakat Desa: Pendekatan Sosiologi Budaya Dalam Masyarakat Aceh. Banda Aceh: Yayasan PeNA.

Marzuki. 2012. Kepemimpinan Perempuan dalam Perspektif Ulama Pesantren di Aceh. Jurnal Ilmiah: Akademika. Vol. 19. No. 01. Januari-Juni 2014.

Mastuhu, 1994. Dinamika Sistem, Pendidikan Pesantren. Jakarta: INIS.

Moleong, Lexy J. 2007. Metodologi Penelitian Kualitatif, Bandung: PT. Remaja Rosdakarya.

Narwoko, Dwi J. dan Suyanto, Bagong. 2004. Sosiologi: Teks Pengantar dan Terapan. Jakarta: Rineke Cipta.

Ritzer, George dan Douglas J. Goodman. 2014. Teori Sosiologi Modern. Edisi ke-7 Jakarta: Kencana.

Sunarto, Kamanto. 2002. Sosiologi Suatu Pengantar. Jakarta: Raja Grafindo Persada.

Sugiyono. 2013. Metode Penelitian Kuantitatif, Kualitatif dan $R$ dan D. Bandung: Alfabeta.

Suni, Ismail. 1980. Bunga Rampai tentang Aceh. Jakarta: Bharata Karya Aksara.

Widyanto, Anton. dkk. 2007. Menyorot Nanggroe: Refleksi Kegundahan atas Fenomena Keagamaan, Pendidikan, Politik, Kepemerintahan, Gerder dan SosialBudaya Aceh. Banda Aceh: Yayasan PeNa. 